\title{
THE SOCIAL ADAPTATION OF YOUTH AND WAYS FOR ITS REALIZATION IN THE CHECHEN REPUBLIC
}

\author{
๑) Zaur I. Enkashev \\ Chechen State University, Grozny, Russian Federation \\ sapsan189@mail.ru
}

Social adaptive mechanisms used in working with young people in the Chechen Republic are examined and analyzed. The history of the formation as well as development of the concepts of "social adaptation" and "social work" is investigated. A comparison of various views and ideas is carried out regarding the possible types of mechanisms of interaction between the individual and the social environment. This topic is relevant among such scientific disciplines as social work, sociology, political science and psychology. By substantiating and comparing various social methods and programs used in the youth policy of the Chechen Republic, fundamental arguments are given on their influence on the formation and development of the modern youth environment of the Chechen Republic. The main focus of the article is on the specifics of clarifying the essence of the fundamental and basic concepts from a single concept of spiritual and moral education and the development of the younger generation of the Chechen Republic.

Key words: social adaptation, development, adaptive processes, spiritual and moral development, youth, environment, society, individual, person, the Chechen Republic, youth policy, social work, innovative technologies, patriotism, state.

\section{[3.И. Энкашев Социальная адаптация молодежи и способы ее реализации в Чеченской Респуб-} лике]

Рассматриваются и анализируются социально-адаптивные механизмы, применяемые при работе с молодежью в Чеченской Республике. Исследуется история формирования и развития понятий «социальная адаптация» и «социальная работа». Проводится сопоставление различных взглядов и идей, касаемо возможных типов механизма взаимодействия личности и социальной среды. Данная тема актуальна в среде таких научных дисциплин как социальная работа, социология, политология и психология. Путем обоснования и сопоставления различных социальных методик и программ, применяемых в молодежной политике Чеченской Республики, приводятся фундаментальные доводы по их влиянию на становление и развитие современной молодежной среды Чеченской Республики. Основной акцент в статье делается на особенности прояснения сути фундаментальных и базовых понятий из единой концепции духовно-нравственного воспитания и развития подрастающего поколения Чеченской Республики.

Ключевые слова: социальная адаптация, развитие, адаптивные процессы, духовно-нравственное развитие, молодежь, окружающая среда, общество, индивид, личность, Чеченская Республика, молодежная политика, социальная работа, инновационные технологии, патриотизм, государство.

Zaur I. Enkashev - Ph.D. student, Law department, Chechen State University, Grozny, Russian Federation.

Энкашев Заур Исаевич - аспирант юридического фракультета, Чеченский государственный университет, г. Грозный, Российская Федерация.

The special place in the discipline of social work is defined to such important term as "adaptation". This concept is formed from the Latin word "adapto" that in translation means "I adapt". Social adaptation can be characterized from various points of view. First, it is the connecting link of the social environment with an object of social work. Secondly, it is the reflection of the result of social work acting as criterion of efficiency. 
One of necessary conditions for the due operational efficiency of the social worker, by right it is considered to be his knowledge of social and adaptive processes. In particular, his knowledge about those processes which happen in the modern developed society. These processes suppose the existence of appropriate technology.

It should be noted that there are a lot of processes thanks to which the person can be, anyway, interdependent with nature. It is very important for the social worker to choose corresponding, and of course, the most suitable techniques and mechanisms of social adaptation correctly. It is about that the human physiology will be in harmony with spiritual qualities. Here the following phrase is appropriate: a sound mind in a sound body.

Besides, in harmony there have to be three components of the person:

1) Feelings (desires, need, requirement);

2) Psychical equilibrium (social values, morals, religion);

3) Rationality (knowledge, judiciousness).

The adaptive stage in human activity is also connected with the person's socialization. In the modern world, it is customary to allocate three levels of social adaptation of the person:

1. Macro environment or society - where adaptive processes of social groups of the population or individual are considered to be interdependent with cultural, spiritual and social aspects of the personality;

2. Microenvironment or group - where either adaptation of the individual or inconsistency of views with public group happen;

3. Individual adaptability - where personal tendency to harmony and pleasure is observed [10, pp. 23-24].

One of the steadily developing territorial subjects in the North Caucasus is the Chechen Republic. In the region the power and parents seek to bring up younger generation without war traces. Thanks to competent approach to this question, there are certain results and advances. As the younger generation of the republic is constantly surrounded with various social relationship, the process of social adaptation bears fruit.

Considering the fact that adaptation has rather various types, such as adaptive fitness to profession, rest, religion, family, principles, etc., with confidence it is possible to tell that any type of social adaptation will cadge from the individual of accomplishment of his functional abilities.

The adjusted and responsible activity of social services which is carried out with youth of the Chechen Republic gives the necessary support at the right time. For the present teenagers did not get into the corresponding social roles, the analysis of their social and adaptive abilities for their socialization is carried out necessarily. The fact that with youth motivational procedures are made is also important. It is very important that each teenager will find himself, and will be able to define the purposes on the future. As their choice also defines their future essence $[9$, p.130].

Thanks to the corresponding analysis and remedial actions of youth policy in the Chechen Republic, necessary results in refraction of unfortunate trends among young people are achieved.

Social adaptation of the Chechen youth to spiritual and moral changes, first of all, is accompanied by cultural activity. In particular, it belongs to the happening changes in educational and leisure spheres. Process with social adaptation to public changes is most complicated as it is connected with several differentiations in the cultural environment [8, pp. 3840].

It is also worth considering that social adaptation is a purposeful interaction of different elements of consciousness and behavior of the person. The main valuable system which is 
external for the individual environment is established for the purpose of compliance and overcoming of disagreements.

One of important conditions of social adaptation of the Chechen youth to the modern social and economic situation is an adequate change in the youth's consciousness. That means the corresponding choice of innovative strategy of economic behavior in society, readiness to bear personal responsibility for own life. Similar changes happen and have equal character. Though many young people among able-bodied population of the Chechen Republic show orientation to their social and economic dependence.

The independent and free individual financially secure and socially recognized is considered to be a priority personality in society. Similar priorities have to be alien for the younger generation of Chechnya.

Though all this is also connected with modernization of the country, however, it does not correspond to the Chechen's cult. Honour and dignity have to be in the priority of everyone. However, sociologists refer to the anemic condition of modern Russian society, and in particular, of youth. Modern rates of development of young people demand from society of advanced forms of development. It leads to the studying of mechanisms of public organization by the social worker.

It is also worth noticing that a social and psychological component of social adaptation, are in inseparable unity.

The mechanism of social adaptation of youth is obliged to be a uniform process of such features of human activity as consciousness and communication among young people of the republic. It is also worth focusing attention on the disclosure of the hidden opportunities of younger generation of Chechnya.

Considering a present condition of young people of the Chechen Republic, it is worth emphasizing, the developed and effectively pursued youth policy by the relevant departments of the republic. This policy is priority as all changes for the better are possible only at improvement of world outlook reference points of younger generation. Only the sane and healthy generation is capable to improve both economic and social stability in the region [6, p. 37].

The Spiritual Administration of Muslims of the Chechen Republic performs enormous work on strengthening of various social institutes, in particular the institution of the family. Much attention in the region is purposefully paid to the education of younger generation, as children and teenagers are the most active and mobile force of society. The youth represents potential force of social and spiritual processes which happen in our country.

First of all, social work has to be directed to the support of development of the healthy, educated and creative person who will uphold the Chechens image and reputation. It is necessary to notice that at this stage of the formation, the youth of the Chechen Republic is a little involved in social practice. According to the last statistics of 2018 , the share of such young people makes only $8 \%$ of the total number of youth of the Russian Federation [3, $p$. 35].

Consequently, the state tries to involve young people in more vigorous social activity. For this purpose, numerous contests for young and perspective people are organized, Presidential grants are allocated so that financially people will not need anything and will be able to realize themselves. However, development of innovative technologies, not always in the best quality affects younger generation of the Chechen Republic. The youth has a choice. To use them for the good or to the detriment. Parents should monitor it in order to avoid bad consequences.

Properly the mechanism of inclusion of youth into the political activity is involved in the region, as teenagers do not always find themselves in intellectual and sports sphere of action [3, p. 38]. 
The important condition for emergence and effective work of the public youth policy is a partner participation in this process of both youth and pre-adolescent organizations and associations [1, p. 8].

In development and formation of youth policy of the Chechen Republic the tasks of social and economic ways of development of the region concerning transition of economy of the Russian Federation to innovative and strategic objectives of the state youth policy in this direction, implemented in the territory of the Chechen Republic are emphasized.

The big problem in achievement of successful results in this direction is represented by the lack of the so-called approach of program type, and for social workers it is worth working on this problem.

It is worth allocating of a couple of subprogram projects which are developed for improvement of youth policy in the region. These are, first of all, such subprograms as: "Guarantee of implementation of the state program in the sphere of youth policy for 2013-2018" and, of course, "Development of education for 2014-2018".

Perhaps, with the most special moment in this program and target activity of the region, it is possible to emphasize the balance of needs for resources and the possibility of their optimization at implementation of the state program. The subprograms selected by us will only promote identification and elimination of already available problems in such spheres as: education and youth policy of the Chechen Republic.

In general, all force of youth policy of the Chechen Republic is directed to the following:

1) Support of talented youth and development of intellectual activity;

2) Formation of cultural and traditional features of behavior among youth;

3) Spiritual and moral education of youth;

4) Preventive actions for prevention of extremism and terrorism;

5) Preventive actions for prevention of road traffic accidents;

6) Social adaptation of the Chechen youth;

7) Patriotic education and promotion of a healthy lifestyle in the environment of youth $[4$, p.19].

For implementation of similar policy numerous events, creative festivals and forums are held in the Chechen Republic. It is also worth noting that in the Chechen Republic there are no orphan homes as well as old people's homes. All necessary conditions for the selfrealization are offered to the citizens with special health needs.

Besides, the corresponding thematic literature is constantly published, materials are published in media so that everyone will be aware and was not deprived. Practically every person has phones, it allows to inform everyone individually. In every possible way, there is an organizational and technical assistance for everyone, for both children's and youth organizations, for associations and clubs.

Today in the Chechen Republic there are about 30 active youth associations. The most massive among them is a youth and public and patriotic movement "Akhmat". Representatives of youth of the Chechen republic, in every possible way participate in interregional, allRussian and international festivals, educational, innovative forums. At the same time, the analysis of the condition of youth policy of the Chechen Republic confirms existence of the certain problems constraining the performance improvement in this sphere [2, p.119].

For elimination of already existing problems, social workers, first of all, need to realize a complex of the actions aimed at the development of activities in such directions as:

- formation of civic consciousness, patriotism, friendship of peoples, continuity of traditions and culture of the Chechen Republic among youth;

- counteraction of distribution of the asocial phenomena among young people of the Chechen Republic; 
- scientific and information support of implementation of youth policy of the Chechen Republic in other directions.

Progress and achievements in implementation of single regional programs, are also caused by application of such social and political technologies as administrative and managerial, educational technologies and technologies of employment. Slow rate of progress of these programs is defined by some factors:

1) insufficient development of technologies of rehabilitation and communicative and information technologies;

2) poor development of information technologies;

3) lack of interregional cooperation in implementation of regional youth policy.

\section{Лumepamypa}

1. Албеков Х.Н., Ялмаев Р.А. Современная муниципальная молодежная политика в Чеченской Республике // ФГУ «Science» 2013. № 1. С. 6-9.

2. Витенберг E.B. Социально-психологические факторы адаптации к социальным и культурным изменениям. СПб., 1994. С. 16-20.

3. Гусев Г.А. Социальная адаптация и педагогическая реабилитация несовершеннолетних. М., 1993. С. 5-32.

4. Илаева 3.М., Яндарбаева Л.А., Гайрбекова Р.С. Мотивация и стимулирование трудовой деятельности персонала // ФГУ «Science» 2015. № 1. C. 118-121.

5. Корель Л.В. Классификация адаптации. Словарь основных понятий. Новосибирск, 1996. С. 12-23.

6. Лисица Е.C. Проблемы и перспективы общественно-политической активности молодежи Северо-Кавказского федерального округа // Власть. 2012. № 5. С. 37.

7. Саралинова Д.С. Приоритеты развития молодежной политики Чеченской Республики // Молодой ученый. 2016. № 11. С. 950-957. Электронный ресурс: https://moluch.ru/archive/115/30857/ (дата обращения: 16.07.2019).

8. Силласте Г.К. Социальная помощь и социальная адаптация детей с ограниченными возможностями. М., 1995. С. 38-40.

9. Социальная работа. Российский Энциклопедический словарь / Под общ. ред. Б.Я. Жукова. М., 1997. С. 128-140.

10. Старикова М.А., Кондря Т.И. Роль социальной работы в России и статус специалиста по социальной работе в обществе // Актуальные вопросы общественных наук: социология, политология, философия, история: сб. статей по материалам X междунар. науч.-практ. конф. Новосибирск: СибАК, 2012. С. 18-40.

11. Теория и методика социальной работы (в вопросах и ответах). М., 1997. С. 138144.

\section{References}

1. Albekov Kh.N., lalmaev R.A. Sovremennaia munitsipal'naia molodezhnaia politika v Chechenskoi Respublike. [Modern municipal youth policy in the Chechen Republic]. Federal State Institution "Science" 2013. No. 1. pp. 6-9 (in Russian).

2. Vitenberg E.V. Sotsial'no-psikhologicheskie faktory adaptatsii k sotsial'nym i kul'turnym izmeneniiam. [Social and psychological factors of adaptation to the social and cultural changes]. Saint Petersburg. 1994. pp. 16-20 (in Russian).

3. Gusev G.A. Sotsial'naia adaptatsiia i pedagogicheskaia reabilitatsiia nesovershennoletnikh. [Social adaptation and pedagogical rehabilitation of minors]. Moscow. 1993. pp. 5-32 (in Russian). 
4. Ilaeva Z.M., landarbaeva L.A., Gairbekova R.S. Motivatsiia i stimulirovanie trudovoi deiatel'nosti personala. [Motivation and stimulation of work of staff]. Federal State Institution "Science". 2015. No. 1. pp. 118-121 (in Russian).

5. Korel L.V. Klassifikatsiia adaptatsii. Slovar' osnovnykh poniatii. [Adaptation classification]. Dictionary of the basic concepts. Novosibirsk. 1996. pp. 12-23 (in Russian).

6. Lisitsa E.S. Problemy i perspektivy obshchestvenno-politicheskoi aktivnosti molodezhi Severo-Kavkazskogo federal'nogo okruga. [Problems and prospects of social and political activity of youth of the North Caucasian Federal District]. Power. 2012. No. 5.37 p. (in Russian).

7. Saralinova D.S. Prioritety razvitiia molodezhnoi politiki Chechenskoi Respubliki. [Priorities of development of youth policy of the Chechen Republic]. Young scientist. 2016. No. 11. 950-957 pp. Available at: https://moluch.ru/archive/115/30857/ (accessed 16 July 2019).

8. Sillaste G.K. Sotsial'naia pomoshch' i sotsial'naia adaptatsiia detei s ogranichennymi vozmozhnostiami. [Public assistance and social adaptation of children with special health needs]. Moscow. 1995. pp. 38-40 (in Russian).

9. Sotsial'naia rabota. Rossiiskii Entsiklopedicheskii slovar'. Pod obshch. red. B.la. Zhukova. [Social work. Russian Encyclopaedic dictionary. Under the general edition of B.Ya. Zhukov]. Moscow.1997. pp. 128-140 (in Russian).

10. Starikova M.A., Kondria T.I. Rol' sotsial'noi raboty v Rossii i status spetsialista po sotsial'noi rabote $v$ obshchestve. [The role of social work in Russia and the status of the specialist in social work in society]. Topical issues of social sciences: sociology, political science, philosophy, history: the collected papers on the materials of the international scientific and practical conference. Novosibirsk: Sibac, 2012. pp. 18-40 (in Russian).

11. Teoriia i metodika sotsial'noi raboty (v voprosakh i otvetakh). [Theory and technique of social work (in questions and answers)]. Moscow. 1997. pp. 138-144 (in Russian). 